\title{
NEW APPROACH TOWARDS BORDER REGIONS IN THE TERRITORIAL AGENDA 2030
}

\author{
Andrzej Jakubowski ${ }^{1}$, Andrzej Miszczuk ${ }^{2}$ iD \\ ${ }^{1}$ Institute of Social and Economic Geography and Spatial Management, Maria Curie-Skłodowska University \\ Al. Kraśnicka 2d, 20-718 Lublin: Poland \\ andrzej.jakubowski@umcs.pl \\ ${ }^{2}$ Institute of Economics and Finance, Maria Curie-Skłodowska University \\ Plac Marii Curie-Skłodowskiej 5, 20-400 Lublin: Poland \\ andrzej.miszczuk@umcs.pl
}

\begin{abstract}
Border regions are commonly perceived as peripheral in terms of transport accessibility and socio-economic development. The peripherality has meant that they have been and continue to be beneficiaries of a traditionally understood - i.e. compensatory - paradigm of regional development. To a large extent, this has been the character of the European Union Cohesion Policy to date. However, a new paradigm of regional development, manifested by the Territorial Agenda 2030, is becoming more and more popular. The article debates possible actions to be taken in regions along national borders to achieve their strategic objectives using the multi-level governance and territorial capital concepts and referring to the six priorities of the Territorial Agenda 2030.
\end{abstract}

Keywords: borderlands, border regions, cross-border regions, regional development, Territorial Agenda 2030.

\section{Introduction}

Border regions are usually treated as unique, mainly because of their location and history (Anderson \& O'Dowd, 1999). Their high vulnerability to changes in international (interstate, transnational) relations, as well as their peripherality in terms of transport accessibility and socio-economic development, especially measured by GDP per capita, is also emphasized (Hansen, 1977; Rietveld, 2012). Specific determinants of their development include their geopolitical location and the nature of the national border. Their socio-economic condition is strongly influenced by existing differences in the level of development in relation to the economies of neighboring regions within the country and across the border (economic distance), as well as institutional distance, related to the inadequacy of competences of bordering administrative regions of different countries and sub-regional units. Finally, the performance of border regions is influenced by differences in the spatial development in relation to border regions, as well as socio-cultural conditions, related to the presence of national and ethnic minorities and stereotypes of the population of neighboring border regions (Chojnicki, 1998; Koter, 2003; Miszczuk, 2012). 
In the body of literature, near-border location is quite commonly perceived as a barrier to development (Miszczuk, 2013). National borders can negatively affect the development of border regions by limiting the area of influence and increasing transaction costs, which adversely affect trade and production (Anderson, O'Dowd \& Wilson, 2003; Clement, 1997). Border regions mainly suffer from efficiency needs because they are not able to use their resources as efficiently as other regions due to their proximity to the border (Capello, Caragliu \& Fratesi, 2018). However, the impact of the border on the development of border regions is strongly contextdependent, and the nature of the border plays an important role in this respect. Research on state borders has long recognized the fluctuation in their function. The role of the border may vary from that of a barrier to that of a contact zone (Ratti, 1993) and from separating to integrating (Martinez, 1994). Więckowski (2019) distinguishes the role of the border as a barrier, the border as a creator of periphery and isolation, the border as a line of differentiation and the border as an axis of cooperation. This means that in different spatial contexts and depending on its function, the impact of the border on regional development may vary.

High hopes for overcoming the adverse effects of border location on regional development are associated with the European integration process (Nelles \& Walther, 2011). It involves the gradual removal of barriers resulting from the existence of traditional national borders and differences related to the functioning of separate legal, fiscal and monetary systems, etc. (Anderson et al., 2003; Decoville \& Durand, 2019; Medeiros, 2018a, 2018b). Integration contributes to the growth of multifaceted economic and social linkages in cross-border areas (Durand \& Decoville, 2020), which often leads to their economic recovery (Basboga, 2020). However, the evolution of border functions towards greater permeability does not trigger an immediate and always positive impact for border regions of the other determinants, i.e.: institutional, economic or socio-cultural (Miszczuk, 2013). Recent studies also confirm that despite the establishment of the European Common Market and the Schengen Area, the economic growth of border regions in the European Union (EU) is still negatively affected by existing legal and administrative barriers (Camagni, Capello \& Caragliu, 2019) and low cross-border accessibility (Medeiros, 2019). In some cases, the differences that emerge in the conditions of integration and the de-bordering processes even lead to the petrification of economic underdevelopment and the consolidation of existing developmental disparities, both in relation to non-border regions within a given country and regions located on the other side of the national border (Jakubowski, 2020).

Consequently, since 1990 - when the Interreg programme was for the first time distinguished within the European Regional Development Fund - border areas in the EU have received particular support, mainly for developing cross-border cooperation and overcoming existing border barriers (Miszczuk \& Jakubowski, 2015; Medeiros, 2018a). However, regional policy towards border areas in EU countries has largely been based on the traditional, i.e. compensatory, paradigm of regional development, which has not always and not everywhere proved to be sufficiently effective (Crescenzi, Fratesi \& Monastiriotis, 2020).

A manifestation of the new paradigm, embedded in European conditions, is the Territorial Agenda 2030 (TA 2030) adopted at the end of 2020 (TA 2030, 2020). It distinguishes six development policy priorities for areas with different development potentials and challenges. Admittedly, only one of these priorities is directly addressed to border regions. However, the remaining priorities can also be successfully used in actions for the development of border regions. Therefore, this paper aims to debate the actions that can be taken in regions located along national borders from the point of view of a new paradigm of regional development, taking into account all six priorities of the TA 2030. 


\section{Between traditional and new paradigms of regional policy}

Socio-economic peripherality meant that border regions were and are treated as a special kind of problem areas (Nijkamp, Rietveld \& Salomon, 1990; Rietveld, 2012; Komornicki, Wiśniewski \& Miszczuk, 2019), becoming beneficiaries of the traditionally understood, i.e. compensatory paradigm of regional development. To a large extent, this has been the nature of EU Cohesion Policy to date, as a significant proportion of border regions were recipients of the policy's first objective, which in 2007-2013 was formulated as: 'Convergence' and in 2014-2020 as 'Investing for Growth and Employment'. The criterion for receiving support was a level of GDP per capita calculated at purchasing power parity, lower than $75 \%$ of the EU average, which was a measure of low level of socio-economic development (Miszczuk \& Jakubowski, 2015).

However, a new paradigm of regional development, based on integrated development undertakings, precisely defined competitiveness factors and strategically selected directions of its enhancement, is becoming more and more popular. The new approach also takes into account a multi-sectoral, place-based approach and an orientation towards compensatory actions in narrowly defined (but nationally relevant) selected areas to discover and exploit potentials of the regions to achieve the 'critical mass' necessary for further development. The role of integrated soft and hard instruments, business environment, social capital, networking, strong coordination and multi-level management is also appreciated. A distinctive feature of the new regional development paradigm is also the differentiated approach to different types of areas, such as growth generating, functionally connected and peripheral (Table 1).

The new approach to regional development policy has also been reflected in initiatives and programmes aimed at border regions. EU Cohesion Policy began to recognize not only the development problems but also the benefits of cooperation between border regions. This approach was reflected in the formulation of one of the three objectives of this policy in the 2007-2013 period and one of the two in the subsequent programming period (2014-2020), referred to as European Territorial Cooperation (ETC). Undertaking various types of joint initiatives of a cross-border nature within the ETC has become an important tool for overcoming existing barriers and solving problems relevant for the economies and inhabitants of border regions (Svensson, 2015; FrątczakMüller \& Mielczarek-Żejmo, 2020; Nienaber \& Wille, 2020). Such relations, focused mostly on common challenges and opportunities in areas such as economic development, infrastructure, environment, or culture, constitute a kind of foundation for cross-border territorial integration (Sousa, 2013). This is also gradually changing the nature and scope of development policy towards and within border areas, which is becoming increasingly oriented towards the cross-border context. Evidence of this shift becomes, for example, the growing importance of cross-border strategic planning and cross-border spatial planning (Jacobs, 2016; Pallagst \& Caesar, 2018). In this way, the new approach to regional development policy in the EU brings about a change in the perception of border areas, presenting them as places of contact and interaction (Ratti, 1993), and in the perception of borders, which are treated as a resource (Sohn, 2014) or even as a developmental opportunity (Nijkamp, 2021). 
Table 1. Traditional and new regional policy paradigms

\begin{tabular}{|c|c|c|}
\hline Specification & $\begin{array}{l}\text { Traditional (old) paradigm: } \\
\text { centralist-equalizing regional policy }\end{array}$ & $\begin{array}{c}\text { A new paradigm: } \\
\text { decentralist-competitive regional policy }\end{array}$ \\
\hline Strategies & Sectoral approach & Integrated development projects \\
\hline \multirow{2}{*}{ Objectives } & $\begin{array}{l}\text { Competitiveness: } \\
\text { Key-word: identifying multiple elements } \\
\text { as factors of competitiveness, resulting in } \\
\text { overlapping of various uncoordinated activities }\end{array}$ & $\begin{array}{l}\text { Competitiveness: } \\
\text { The main element of the new regional policy } \\
\text { (diffusion of growth), precisely defined factors } \\
\text { of competitiveness and strategically selected } \\
\text { directions of its enhancement, multi-sectoral, } \\
\text { territorially oriented approach }\end{array}$ \\
\hline & $\begin{array}{l}\text { Alignment: } \\
\text { Strong emphasis on compensatory measures, } \\
\text { but the effect is limited in relation to that } \\
\text { intended - widening of disparities, dispersion } \\
\text { of resources }\end{array}$ & $\begin{array}{l}\text { Alignment: } \\
\text { Countervailing measures on a narrower scale, } \\
\text { relevant for the whole country, in selected } \\
\text { areas, for discovering and exploiting their } \\
\text { potentials, allowing to reach a 'critical mass' } \\
\text { necessary for further development }\end{array}$ \\
\hline Tools & Subsidies and state aids & $\begin{array}{l}\text { Integrated soft and hard instruments, business } \\
\text { environment, social capital, networking, better } \\
\text { coordination }\end{array}$ \\
\hline $\begin{array}{l}\text { Territorial } \\
\text { dimension }\end{array}$ & $\begin{array}{l}\text { Regions treated homogenously, without } \\
\text { taking into account their internal and external } \\
\text { diversity, territorial dimension poorly taken } \\
\text { into account, primacy of sectoral approach, } \\
\text { 'poverty algorithm' }\end{array}$ & $\begin{array}{l}\text { Territorial approach in all development } \\
\text { activities, recognition of diversity, strong } \\
\text { coordination, multi-level governance, } \\
\text { integrated programmes dedicated to areas of } \\
\text { strategic intervention }\end{array}$ \\
\hline $\begin{array}{l}\text { Territorial } \\
\text { units }\end{array}$ & $\begin{array}{l}\text { Administrative units: } \\
\text { Lack of consideration of urban-rural relations } \\
\text { in policy instruments, rural areas perceived } \\
\text { equally across the country }\end{array}$ & $\begin{array}{l}\text { Functional units: } \\
\text { Differentiated approach to different types } \\
\text { of territories; place-based policies taking } \\
\text { into account the interdependence of growth } \\
\text { generating areas, functionally linked areas and } \\
\text { peripheral areas }\end{array}$ \\
\hline Actors & Government and local government & $\begin{array}{l}\text { All levels of public administration, social actors } \\
\text { and business representatives - empowerment } \\
\text { of multi-level governance }\end{array}$ \\
\hline
\end{tabular}

Source: authors' compilation based on OECD (2010).

\section{Territorial Agenda 2030 as an example of a new approach in regional policy}

A manifestation of a new paradigm of regional development (including border regions), embedded in European conditions, is the TA 2030 adopted at the end of 2020 (TA 2030, 2020). It is an intergovernmental strategy for Europe and its regions, presenting a common vision of spatial development of the European area. It is not the first document of its kind but rather follows a series of earlier similar documents like The European Spatial Development Perspective (ESDP) adopted in 1999 by the Council of Ministers responsible for Spatial Planning, Territorial Agenda of the European Union (TA) adopted in 2007 and Territorial Agenda of the European Union 2020 (TA 2020) adopted in 2011 by the by Ministers responsible for spatial planning and development (Neto, 2020). The TA 2030 resulted from intergovernmental cooperation on spatial and urban policy, comprising initiatives, policies and documents that have been developed in dialogue between Member States and the Commission. Like other documents of this type, TA 2030 is a non-binding document. However, 
based on the power of the dialogue process, it can become a guiding document for national and European policies, even it is formally distinguished from Cohesion Policy instruments (Dallhammer, Gaugitsch, Neugebauer \& Böhme, 2018).

TA 2030 emphasizes cross-border links and cooperation, the social dimension of cohesion and spatial aspects of development, as well as the role of cities and functional areas. The document includes recommendations for more effective implementation of the EU policies, paying attention to spatial impacts of these policies and their effects on the lives of EU citizens. It also indicates actions necessary to strengthen territorial cohesion, i.e. to ensure good living conditions for all inhabitants of Europe, regardless of where they live and work. TA 2030 identifies two areas for strategic action in Europe up to 2030, which are defined as: 1) A Just Europe, 2) A Green Europe.

The first of these areas includes three priorities:

- Better balanced territorial development utilizing Europe's diversity,

- Convergent local and regional development, less inequality between places,

- Easier living and working across national borders,

and the second one - another three:

- Better ecological livelihoods, climate-neutral and resilient towns, cities and regions,

- Strong and sustainable local economies in a globalized world,

- Sustainable digital and physical connectivity of places.

Five spatial dimensions have been defined for these priorities, i.e.: transnational, cross-border, national, regional and local. Out of the mentioned six priorities, only one is directly addressed to border regions. In the further part of the article, an attempt was made to analyze the conditions and possibilities of concretization of measures taking into account also other priorities from the point of view of a new paradigm of regional development, which can be undertaken in regions located along national borders.

\section{Territorial Agenda 2030 and border regions}

\section{Just Europe and border regions}

The priorities from the strategic action area, called 'A Just Europe', which aim to counteract the growing inequalities in Europe, are based on:

- economic, social and territorial cohesion,

- European Pillar of Social Rights,

- a vision of a more citizen-oriented and inclusive Europe,

- sustainable and integrated development of different areas,

- a just transition for EU economies to achieve climate neutrality by 2050,

- territorial integration with a European dimension.

The territorial aspect of these priorities and the importance of spatial planning in achieving them are highlighted. The first two priorities recognize the significant development potential of Europe due to its diversity in transnational and national dimensions, but also in regional and local dimensions. The cross-border dimension can also be added here, because - as noted in the introduction - border regions often have unique development resources. The identification of development opportunities in spatial differentiation stems from the place-based approach used in the TA 2030, which first appeared in 2009 in a report prepared by Barca in support of Cohesion Policy 
reform for regions in EU Member States (Barca, 2009). A manifestation of the operationalization of the place-based approach is the concept of territorial capital, which should be considered as the basis for the endogenous development of each territory. Territorial capital can be defined as a set of resources (assets) of different types that characterize a territory (Camagni, Caragliu \& Perucca, 2011). This applies especially to unique and unrepeatable resources, the use of which creates the competitive potential of the territory (Przygodzki, 2016).

Territorial capital is the resultant of the state, transformation and impact of elementary development factors building its relational structure (Przygodzki, 2016). Its components are (Churski, Herodowicz, Konecka-Szydłowska \& Perdał, 2019):

- human capital, described by demographic situation, health status, mobility, qualifications and skills and labor market status,

- social capital (bonding and bridging), including social activity, activities of NGOs, local organizations and associations, entrepreneurship and social dysfunctions,

- physical capital, consisting of natural resources and the state of the natural environment, as well as technical and social infrastructure,

- financial capital characterized by the financial situation of enterprises, population and public administration, the state and structure of financial services, the volume and structure of absorption of European public funds, external financial capital flows,

- innovations resulting from the innovativeness (process) and the creation of an innovation environment.

More complete systematics in this respect was proposed in his model by Camagni et al. (2011), distinguishing between bonding and bridging social capital, calling the former social capital and the latter relational capital. He used two criteria for the division, i.e.: competition for goods and the nature of the goods (Table 2).

Table 2. Components of territorial capital

\begin{tabular}{|c|c|c|c|}
\hline \multirow[b]{2}{*}{ Rivarly } & \multicolumn{3}{|c|}{ Materiality } \\
\hline & $\begin{array}{l}\text { tangible goods } \\
\text { (hard) }\end{array}$ & $\begin{array}{c}\text { mixed } \\
\text { (hard + soft) }\end{array}$ & $\begin{array}{l}\text { intangible goods } \\
\text { (soft) }\end{array}$ \\
\hline $\begin{array}{l}\text { private goods } \\
\text { (high rivalry) }\end{array}$ & $\begin{array}{l}\text { private fixed capital stock, } \\
\text { pecuniary externalities (hard), } \\
\text { toll goods }\end{array}$ & $\begin{array}{l}\text { relational private services } \\
\text { operating on: } \\
\text { - external linkages for firms, } \\
\text { - transfer of R\&D results } \\
\text { university spin-offs }\end{array}$ & $\begin{array}{l}\text { human capital: } \\
\text { - entrepreneurship, } \\
\text { - creativity, } \\
\text { - private know-how } \\
\text { pecuniary externalities ('soft') }\end{array}$ \\
\hline $\begin{array}{l}\text { club goods and } \\
\text { impure public } \\
\text { goods } \\
\text { (moderate } \\
\text { rivalry) }\end{array}$ & $\begin{array}{l}\text { proprietary networks } \\
\text { collective goods: } \\
\text { - landscape, } \\
\text { - cultural heritage (private } \\
\text { 'ensembles') }\end{array}$ & $\begin{array}{l}\text { cooperation networks: } \\
\text { - strategic alliances in R\&D } \\
\text { and knowledge, } \\
\text { - public-private partnerships } \\
\text { in services and schemes, } \\
\text { governance on land and } \\
\text { cultural resources }\end{array}$ & $\begin{array}{l}\text { relational capital: } \\
\text { - associationism, } \\
\text { - cooperation capacibility, } \\
\text { - collective action capability, } \\
\text { - collective competencies }\end{array}$ \\
\hline $\begin{array}{l}\text { public goods } \\
\text { (low rivalry) }\end{array}$ & $\begin{array}{l}\text { resources: } \\
\text { - natural, } \\
\text { - cultural (punctual), } \\
\text { social overhead capital: } \\
\text { - infrastructure }\end{array}$ & $\begin{array}{l}\text { agencies for R\&D transcoding } \\
\text { receptivity enhancing tools } \\
\text { connectivity } \\
\text { agglomeration and district } \\
\text { economies }\end{array}$ & $\begin{array}{l}\text { social capital (civicness): } \\
\text { - institutions, } \\
\text { - behavioral models, values, } \\
\text { - trust, reputation }\end{array}$ \\
\hline
\end{tabular}

Source: Camagni et al. (2011, p. 5), adjusted by the authors. 
In turn, Szafranek (2019) proposed four components of territorial capital (Table 3).

Table 3. Components and features of territorial capital

\begin{tabular}{|l|l|}
\hline \multicolumn{1}{|c|}{ Components } & \multicolumn{1}{|c|}{ Features and examples } \\
\hline Entities & $\begin{array}{l}\text { Inhabitants, local authorities, NGOs, entrepreneurs and employees, supplies } \\
\text { and other partners }\end{array}$ \\
\hline Characteristics & $\begin{array}{l}\text { Intangibles, they can be maximized and managed } \\
\text { Requires financial and non-financial investments (time costs of building trust } \\
\text { and organizational culture) } \\
\text { Benefits shaped by formal and informal activities, achieved in the long term }\end{array}$ \\
\hline Benefits & $\begin{array}{l}\text { Benefits of the territory as a collective and its individual actors } \\
\text { Increased trust and commitment of stakeholders } \\
\text { Improving satisfaction and willingness to cooperate } \\
\text { Caring for the reputation and image of the territory } \\
\text { Improving the attractiveness of the territory }\end{array}$ \\
\hline Ways and conditions of creation & $\begin{array}{l}\text { Overarching priority - development of social capital } \\
\text { Creation in a continuous process through experience } \\
\text { Feedback on the relationship between all resources } \\
\text { Purchase and imitation impossible } \\
\text { Imitation difficult and questionable. }\end{array}$ \\
\hline
\end{tabular}

Source: Szafranek (2019, p. 78).

Three dimensions can be distinguished in territorial capital (Nowakowska, 2017):

- geographical, created both by the availability of common and classic resources of a material nature, as well as - specific resources (tangible and intangible) determining the competitive advantage of the territory, and also the spatial proximity occurring within its framework which strengthens the intensity and density of relations occurring between entities and contributes, inter alia, to the exchange of information and the creation of knowledge and innovation;

- relational, which shows the embedding of economic activity and its effects in a social environment, created by social structures and relations (trust, bonding, identity, belonging), as well as economic, cultural and historical norms and values;

- institutional, showing how the territory is organized and how the behavior of the actors in it is coordinated, including informal organizations and institutional proximity (shared customs, rules and procedures for cooperation), which fosters information exchange, cooperative processes, interactive and collective learning and reduces risks and transaction costs.

The question is how the spatial differentiation of development described by territorial capital can be used to improve the economic, social and territorial cohesion of Europe, with particular reference to border regions. TA 2030 proposes, among other, the following actions in this respect (TA 2030, 2020):

- cooperation and the creation of polycentric networks of cities, metropolitan areas and regions (also with the involvement of EU Member State authorities) which are intended, on the one hand, to prevent excessive concentration of population and economic activity and, on the other, to foster better working, living and business conditions in all parts of Europe by contributing to economic prosperity, their innovation capacity, position in global value chains and global competitiveness;

- the inclusion, in a polycentric development model, of small and medium-sized towns, which can play a special role in counteracting socio-economic and spatial polarization, provided they have international transport accessibility and adequate access to local and regional services, which is particularly important in border regions, 
- cooperation of various levels of governing bodies to make comprehensive use of the unique qualities of sea coasts, islands, river valleys, mountain ranges, lake districts, plains or inner peripheries; it should be added that these specific areas are often border regions, which require international (cross-border) cooperation between public administrations at various levels;

- treating cities, which are the engines of socio-economic development, attractive places to live, work, visit or invest, in terms of functional areas, also covering neighboring administrative units under the influence of the city, which will contribute to a coordinated development policy that will be beneficial to both the city and its hinterland.

A special role can be played by cities in border regions, especially if they have the character of the so-called 'divided cities' or twin towns (Miszczuk \& Jakubowski, 2019). The removal of barriers separating different parts of these cities and the restoration of their functional regions may contribute to the coherent socio-economic development of the border region.

The third priority of the TA 2030 is related to the integration across borders, which aims to ensure easier living and working in border regions. This may be achieved by enhancing stable cross-border cooperation at national, regional and local levels, implementation of joint development strategies and dialogue with policy-makers at all levels to coordinate national sector policies between countries and reduce existing barriers (Böhme, Lüer, Ferry, McMaster \& Palenberg, 2020). Cooperation between land and maritime areas belonging to different countries allows for better use of their development potential and identification of challenges, e.g. through joint projects implemented under the Interreg programme, as well as institutionalization of cooperation through the establishment and operation of European Groupings of Territorial Cooperation (EGTC). An EGTC may be created by partners established in at least two EU Member States and belonging to at least one of the following categories: Member States, regional authorities, local authorities, public law bodies and associations with the aim, i.e., of operating cross-border transport infrastructure or hospitals, implementing or managing cross-border development projects, exchanging experience and good practice and managing joint cross-border programmes financing projects of common interest to the EGTC partners. The advantages of setting up an EGTC are that it creates a single legal entity and uses a single set of rules to carry out joint initiatives in at least two Member States, that it allows cooperation on joint initiatives without the need for an international agreement requiring ratification by national parliaments, and that it allows Member States to respond jointly and directly to calls for proposals launched under EU territorial programmes and to act as a single managing authority. At the sub-regional level, cross-border cooperation can also be developed on the basis of such instruments as Integrated Territorial Investments (ITI) and Community-Led Local Development (CLLD) which may mobilize and involve local communities and organizations to contribute to the implementation of the TA 2030 goals using resources in the area to address local challenges.

Cross-border integration - as highlighted in the Agenda - is about creating a critical mass for development and generating synergies to reduce economic, social and environmental fragmentation and negative externalities in border regions. The planes of this integration may be ecosystems, natural and cultural heritage, labor markets, public services or a network of cities divided by borders, and its instruments: cross-border, transnational, interregional development strategies at macroregional, national, regional and local level. TA 2030 promotes also intermetropolitan cooperation, functional regions governance (Kurowska-Pysz, Jakubowski, Spiriajevas \& Studzieniecki, 2021), as well as various cross-border planning and legal cross-border agreements. All the instruments mentioned above are not new. However, the TA 2030 demonstrates how they can be used effectively to facilitate stable cooperation between administrative areas beyond single 
projects, 'better aligned with long-term, cross-border economic strategies to create sustainable cross-border development' (Klatt \& Winkler, 2020).

The main problems hindering the deepening of cross-border cooperation and integration are, to a large extent, of a legal and administrative nature and stem from the different legal systems and procedures within them. They concern various aspects such as the different structures of public administration and their competencies, different tax, social and health insurance laws, different spatial planning systems and its legal basis and different environmental laws. It also applies to unsolved everyday border problems and absurdities, currency exchange rate differences, especially at the external borders of the euro area, different transport systems inadequate for the needs of border areas, incompatibility of education and e-administration systems. Certain problems are also generated by the loss of security due to the opening of borders, with inefficient cross-border police cooperation, the increase in cross-border tourism as a factor for environmental destruction and difficulties in cross-border training of workers, which makes it difficult to open up the European labor market to them. And last, but not least, cross-border integration is still negatively affected by language barriers, as well as prejudices and stereotypes in the perception of neighbors. A coordination effort is therefore needed to tackle these problems (some of which will take time) in border areas (EC, 2020a; Medeiros, Ramírez, Dellagiacoma \& Brustia, 2021).

These problems can be overcome with the involvement of the various actors operating at different, i.e. supra-national, national, cross-border, regional and local levels and by the harmonization of theirs actions (integrated multi-level governance approach). In Europe, cross-border cooperation enhances the development of a soft, but institutionalized, comprehensive, stable and territorially-defined layer in the European 'multi-level-system' at cross-border dimension and proliferation of different governance structures and organizations (Blatter, 2004; Fricke, 2015). They complement other levels of governance playing a crucial role in the development of the common cross-border strategies and its implementation. They also provide a necessary means to address common problems and opportunities (Sousa, 2013). The solutions proposed in TA 2030 follow the logic of strengthening territorial cohesion in the EU by stimulating territorial development in border regions, but they aim to direct the focus of cross-border governance closer to the border. This is all the more important as until now the territoriality of the EU practice of stimulating regional cross-border cooperation sometimes hindered cross-border governance (Terlouw, 2012).

\section{Green Europe and border regions}

The overall objective of Green Europe is to protect people's livelihoods and achieve social transformation, following the UN Sustainable Development Goals, the Convention on Biological Diversity, the European Green Deal, the Paris Agreement, the EU Biodiversity Strategy 2030, the European Landscape Convention, and the EU Forestry Strategy. The priority is about creating greener living conditions, climate neutrality by 2050 and safer (resilient) cities and regions. The functioning of ecosystems (agricultural, forestry, grassland, water, marine, etc.) and the services they provide are essential in supporting long-term sustainable development. It is essential to curb climate change, which is reducing biodiversity and weakening ecosystem functioning, thereby worsening people's living conditions and also their incomes. Thus, integrated development management should be based on a nature-based approach and consist of the creation of green and blue infrastructure. Spatial planning should play a special role in this regard. Crisis management related to the analysis of risks and effects of environmental disasters should also be an element of integrated development management. Border regions should play a special role in this respect because: 
- it is common for ecosystems to be divided by national borders, which can disrupt their functioning, and counteracting this phenomenon requires transnational cooperation involving national governments and parliaments and cross-border cooperation involving regional and local authorities (Więckowski, 2018);

- the socio-economic peripherality of border regions also generally means lower anthropopressure in their areas, and thus the easier achievement of sustainable development objectives;

- counteracting natural disasters in border regions necessitates more complicated coordination of the activities of various actors on both sides of the border.

The following actions proposed by Ricq (2006) therefore remain valid:

- preparation of joint studies on environmental pollution and its remediation;

- implementation and management of environmental programmes;

- provision of the information on actual and potential risks to the environment;

- creation of a common database on plant and animal species;

- creation of cross-border nature parks and joint projects on clean rivers and lakes,

- initiation of joint spatial planning policies and harmonization of spatial plans on both sides of the border;

- setting up an early warning system on threats.

Another priority of Green Europe is to strengthen and balance local economies in a globalized world, based on a circular (closed) model. A circular economy means breaking with the so-called linear model, which is dominant nowadays and functions according to the principle: 'take produce - use - throw away'. A circular economy refers to the functioning of natural ecosystems. It is based on continuous processing and recovery of materials, raw materials and energy by means of recycling, eco-design, regeneration, reduction and recovery applied to the whole economic system from production to consumption and at every level (from local to global) (CIRTOINNO, 2021).

In European practice, the application of circular economy solutions should be manifested by decarbonization, which will significantly contribute to climate neutrality. It is worth emphasizing the special role of border regions in this respect. On the one hand, for geopolitical reasons, they often have not been the location of traditional industries. On the other hand, the fact of a possible division of former coal basins and steel districts (e.g. historic Silesia) by a state border of a subsequent nature, provides an additional impulse to undertake joint restructuring activities in a cross-border (transnational) dimension.

Green Europe's third priority is related to the sustainable digital and physical connectivity between areas. The Covid-19 pandemic demonstrated the usefulness of online networks for both e-economy and e-government. This type of connectivity also has an environmental dimension, related to the absence of the need for physical movement. The emergence of virtual space also improved access to services and thus increased spatial justice (Szczepaniec \& Jurkiewicz, 2020). However, the problem of sparsely populated border areas may be the low availability of internet networks (especially broadband) and often associated mobile phone networks.

The development of the Internet does not imply a total substitution of travel in the physical sense. It is important for border regions, i.e., to monitor cross-border connections and to prepare joint projects for the development of major elements of technical infrastructure (road, rail, air, river, sea, border), as well as to analyze the transport needs of the population living near the border and to organize a cross-border public transport system. Efforts to optimize cross-border road, rail and air transport may include joint use of transport infrastructure nodes (e.g. airports) for border regions on both sides of the border. 


\section{Summary}

In comparison to the preceding documents (ESDP, TA, TA 2020), the TA 2030 calls for a greater attention to be paid to borders and border areas in the EU. It promotes better policy coordination across countries in supporting cross-border functional regions and ensuring, that cross-border cooperation is embedded within development strategies adopted at European, national, regional local levels and aims to address common problems and exploit existing potentials and local assets in order to reduce disparities and improve integration across the borders.

The TA 2030 is the manifestation of a new approach to regional development policy that can be used in border regions. The novelty of the approach to achieving its strategic objectives lies in the extensive use of the concept of multi-level governance in the transnational, national, cross-border, regional and local dimensions, as well as the concept of territorial capital, which is used for multi-criteria evaluation of development potential and is derived from a 'territorially oriented' approach. This is intended, on the one hand, to provide a broad assessment of the development potential of, i.e., border regions and, on the other, to achieve a high degree of social, economic and territorial cohesion at the European level. Utilizing a new approach to regional development policy, TA 2030 does not develop new solutions but rather identifies the most appropriate measures responding to current challenges to foster the development of border areas. It integrates the bottom-up and top-down modes of governance in cross-border arrangements into a common multi-level framework. It also promotes synergies between the Territorial Agenda and overarching EU strategies and policies (Neto, 2020). Last but not least it integrates place-based approaches and coordination of sector policies in terms of their territorial impacts and coherence.

This new approach is already reflected by the innovations in the 2021-2027 proposal for Cohesion Policy in general, and for ETC in particular. On the one hand, they refer to the well-established concepts of 'territorial cohesion', 'place-based approach' and 'smart specialization' which underpinned the cohesion policy in general and ETC in 2007-2013 and 2014-2020. On the other hand, they aim to improve theirs efficiency by the increase in the use of integrated territorial approaches like ITI, CLLD and Research and Innovation Strategies for Smart Specialization (RIS3), and new ways of broader engagement of the EGTCs in the governance of Interreg programmes. The EC's draft legislation and orientation papers for the 2021-2027 period also seek to orientate cross-border programmes on 'borders where there is a high degree of cross-border interaction' (EC, 2018, p. 5). This approach seems to be underpinned by the aspiration to better integrate cross-border areas and overcome existing barriers more effectively (which has been a major objective of Interreg since its creation). It also proposes to go beyond spatially defined cross-border regions by providing a more flexible framework for place-based actions 'to ensure service provision, economic development, mobility, etc.' (EC, 2020b, p. 28). The implementation of the TA 2030 could bring the reorientation of the Cohesion Policy which could be used then as a real 'development/cohesion policy tool, as opposed to the investment tool it has become in recent decades' (Medeiros, 2020, p. 7).

The Territorial Agenda, however, is not a document lacking in any flaws and weaknesses. Its conceptual framework does not offer enough clarity and specificity (Neto Henriques, Dragović, Auer \& Gomes, 2020). TA 2030 may, therefore, became 'just another invisible and ineffective strategic report on policy' (Medeiros, 2020, p. 7). Another shortcoming of the TA 2030 is the lack of a clear position on the radical change of measures for assessing the level of development, especially GDP per capita, increasingly widely advocated in the scientific community (Dasgupta, 2021). Moving away from this traditional measure of development would ensure that border regions would not be perceived as peripheral or underdeveloped, but would become regions of new development opportunities. 


\section{References}

Anderson, J., \& O'Dowd, L. (1999). Borders, Border Regions and Territoriality: Contradictory Meanings, Changing Significance. Regional Studies, 33(7), 593-604. https://doi. org/10.1080/00343409950078648

Anderson, J., O'Dowd, L., \& Wilson, T. M. (Eds.). (2003). New Borders for a Changing Europe: Cross-border cooperation and Governance. London: Routledge.

Barca, F. (2009). An agenda for a reformed Cohesion Policy. A place-based approach to meeting European Union challenges and expectations. Retrieved from https://ec.europa.eu/regional_policy/ archive/policy/future/pdf/report_barca_v0306.pdf

Basboga, K. (2020). The role of open borders and cross-border cooperation in regional growth across Europe. Regional Studies, Regional Science, 7(1), 532-549. https://doi.org/10.1080/21681376.2020 .1842800

Blatter, J. (2004). From 'spaces of place' to 'spaces of flows'? Territorial and functional governance in cross-border regions in Europe and North America. International Journal of Urban and Regional Research, 28(3), 530-548. https://doi.org/10.1111/j.0309-1317.2004.00534.x

Böhme, K., Lüer, C., Ferry, M., McMaster, I., \& Palenberg, D. (2020). Implementing the Territorial Agenda 2030. Examples for a territorial approach in policy design and delivery. Federal Ministry of the Interior, Building and Community.

Camagni, R., Capello, R., \& Caragliu, A. (2019). Measuring the impact of legal and administrative international barriers on regional growth. Regional Science Policy \& Practice, 11(2), 345-366. https://doi. org/10.1111/rsp3.12195

Camagni, R., Caragliu, A., \& Perucca, G. (2011). Territorial capital. Relational and human capital. Milan: Politecnico di Milano.

Capello, R., Caragliu, A., \& Fratesi, U. (2018). Measuring border effects in European cross-border regions. Regional Studies, 52(7), 986-996. https://doi.org/10.1080/00343404.2017.1364843

Chojnicki, Z. (1998). Uwarunkowania rozwoju regionu nadgranicznego. Koncepcje i założenia teoretyczne. In B., Gruchman \& J., Parysek (Eds.). Studia rozwoju i zagospodarowania przestrzennego (vol. 2, pp. 11-48). Poznań: Wydawnictwo Akademii Ekonomicznej.

Churski, P., Herodowicz, T., Konecka-Szydłowska, B., \& Perdał, R. (2019). Czynniki rozwoju w praktyce polityki spójności zorientowanej terytorialnie. In J., Danielewicz \& D., Sikora-Fernandez (Eds.). Zarzqdzanie rozwojem współczesnych miast (pp. 141-164). Łódź: Wydawnictwo Uniwersytetu Łódzkiego.

CIRTOINNO (2021). Circular Economy Tools to Support Innovation in Green and Blue Tourism SMEs. Retrieved from https://cirtoinno.eu/pl/circular-economy

Clement, N. (1997). The Changing Economics of International Borders and Border Regions. In P., Ganster, A., Sweedler, J. W., Scott, \& W.-D., Eberwein (Eds.). Borders and Border Regions in Europe and North America (pp. 47-63). San Diego, CA: San Diego State University Press.

Crescenzi, R., Fratesi, U., \& Monastiriotis, V. (2020). Back to the member states? Cohesion Policy and the national challenges to the European Union. Regional Studies, 54(1), 5-9. https://doi.org/10.1080/0 0343404.2019.1662895

Dallhammer, E., Gaugitsch, R., Neugebauer, W., \& Böhme, K. (2018). Spatial planning and governance within EU policies and legislation and their relevance to the New Urban Agenda. European Union. Retrieved from https://cor.europa.eu/en/engage/studies/Documents/Spatial-planning-new-urban-agenda.pdf

Dasgupta, P. (2021). The Economics of Biodiversity: The Dasgupta Review. London: HM Treasury.

Decoville, A., \& Durand, F. (2019). Exploring cross-border integration in Europe: How do populations cross borders and perceive their neighbours? European Urban and Regional Studies, 26(2), 134-157. https://doi.org/10.1177/0969776418756934

Durand, F., \& Decoville, A. (2020). A multidimensional measurement of the integration between European border regions. Journal of European Integration, 42(2), 163-178. https://doi.org/10.1080/070 36337.2019.1657857 
EC (2018). Proposal for a Regulation of the European Parliament and of the Council on specific provisions for the European territorial cooperation goal (Interreg) supported by the European Regional Development Fund and external. COM(2018) 374 final. European Commission.

EC (2020a). B-solutions. Solving border obstacles: A compendium of 43 cases. Association of European Border Regions \& European Union. Luxembourg: Publications Office of the European Union.

EC (2020b). Joint paper on Interreg NEXT Strategic Programming 2021-2027. Interreg NEXT programmes on EU external borders with the neighbouring partner countries. Europan Commision.

Frątczak-Müller, J., \& Mielczarek-Żejmo, A. (2020). Networks of cross-border cooperation in Europe - the interests and values. The case of Spree-Neisse-Bober Euroregion. European Planning Studies, 28(1), 8-34. https://doi.org/10.1080/09654313.2019.1623972

Fricke, C. (2015). Spatial Governance across Borders Revisited: Organizational Forms and Spatial Planning in Metropolitan Cross-border Regions. European Planning Studies, 23(5), 849-870. https://doi. org/10.1080/09654313.2014.887661

Hansen, N. (1977). Border regions: A critique of spatial theory and a European case study. The Annals of Regional Science, 11(1), 1-14. https://doi.org/10.1007/BF01287245

Jacobs, J. (2016). Spatial planning in cross-border regions: A systems-theoretical perspective. Planning Theory, 15(1), 68-90. https://doi.org/10.1177/1473095214547149

Jakubowski, A. (2020). Asymmetry of the economic development of cross-border areas in the European Union: Assessment and typology. Europa XXI, 39, 45-62. https://doi.org/10.7163/Eu21.2020.39.6

Klatt, M., \& Winkler, I. (2020). Lessons from the Danish-German Border Region for Post 2020 Interreg A - an Alignment with Cross-Border Functional Regions? Europa XXI, 38, 139-156. https://doi. org/10.7163/Eu21.2020.38.5

Komornicki, T., Wiśniewski, R., \& Miszczuk, A. (2019). Delimitacja przygranicznych obszarów problemowych [The delimitation of problem border areas]. Przeglqd Geograficzny, 91(4), 467-486. https://doi.org/10.7163/PrzG.2019.4.2

Koter, M. (2003). Multicultural Border Regions of Europe - Forms of Ethnic Composition and Process of their Differentiation. Region and Regionalism, 6, 13-22.

Kurowska-Pysz, J., Jakubowski, A., Spiriajevas, E., \& Studzieniecki, T. (2021). Identification of key elements for creating the Touristic Cross-border Functional Area at the Lithuanian-Polish border. Final report. Ref. Ares(2021)2676617-21/04/2021. European Commission.

Martinez, O. J. (1994). The Dynamics of Border Interaction. New Approaches to Border Analysis. In C., Schofield (Ed.). Global Boundaries I: world boundaries. London: Routledge.

Medeiros, E. (2018a). The Role of European Territorial Cooperation (ETC) in EU Cohesion Policy. In E., Medeiros (Ed.). European Territorial Cooperation. Theoretical and Empirical Approaches to the Process and Impacts of Cross-Border and Transnational Cooperation in Europe. Cham: Springer International Publishing.

Medeiros, E. (2018b). Should EU cross-border cooperation programmes focus mainly on reducing border obstacles? Documents d'Anàlisi Geogràfica, 64(3), 467. https://doi.org/10.5565/rev/dag.517

Medeiros, E. (2019). Cross-border transports and cross-border mobility in EU border regions. Case Studies on Transport Policy, 7(1), 1-12. https://doi.org/10.1016/j.cstp.2018.11.001

Medeiros, E. (2020). Editorial: EU post-2020 territorial policies? Europa XXI, 38, 5-8. https://doi. org/10.7163/Eu21.2020.38.9

Medeiros, E., Ramírez, M. G., Dellagiacoma, C., \& Brustia, G. (2021). Will reducing border barriers via the EU's b-solutions lead towards greater European territorial integration? Regional Studies. https://doi. org/10.1080/00343404.2021.1912724

Miszczuk, A. (2012). Dysproporcje społeczno-ekonomiczne jako uwarunkowanie współpracy transgranicznej (na przykładzie pogranicza polsko-ukraińskiego). In M., Kowerski \& I., Pieczykolan (Eds.). Kadry dla gospodarki transgranicznej (pp. 37-50). Zamość: Wyższa Szkoła Zarządzania i Administracji w Zamościu.

Miszczuk, A. (2013). Uwarunkowania peryferyjności regionu przygranicznego. Lublin: Norbertinum.

Miszczuk, A., \& Jakubowski, A. (2015). Evolution of the European Union Cohesion Policy Towards Border Regions. In A. J., Kukuła (Ed.). Cohesion policy and development of the European Union's regions in the perspective of 2020 (pp. 169-191). Lublin: Wydawnictwo KUL. 
Miszczuk, A., \& Jakubowski, A. (2019). Borders and Border Cities in Transition: Towards a Typology. Barometr Regionalny. Analizy i Prognozy, 17(1), 7-14. https://doi.org/10.35480/BRAiP-2019.17.1-720

Nelles, J., \& Walther, O. (2011). Changing European borders: From separation to interface? An introduction. Articulo, 6. https://doi.org/10.4000/articulo.1658

Neto Henriques, C., Dragović, S., Auer, C., \& Gomes, I. (2020). The Territorial Agenda 2030: Towards a common language? A review of a conceptual framework. Europa XXI, 38, 157-174. https://doi. org/10.7163/Eu21.2020.38.8

Neto, P. (2020). EU Cohesion Policy post-2020, European Green Deal and Territorial Agenda 2030. The future of the place-based approach in the new EU policy framework in the context of COVID-19. Europa XXI, 38, 33-50. https://doi.org/10.7163/Eu21.2020.38.2

Nienaber, B., \& Wille, C. (2020). Cross-border cooperation in Europe: A relational perspective. European Planning Studies, 28(1), 1-7. https://doi.org/10.1080/09654313.2019.1623971

Nijkamp, P. (2021). Borders as opportunities in the space-economy: Towards a theory of enabling space. Asia-Pacific Journal of Regional Science, 5(1), 223-239. https://doi.org/10.1007/s41685-021-00191-x

Nijkamp, P., Rietveld, P., \& Salomon, I. (1990). Barriers in spatial interactions and communications: A conceptual exploration. The Annals of Regional Science, 24(4), 237-252. https://doi.org/10.1007/ BF01580472

Nowakowska, A. (2017). Terytorializacja rozwoju i polityki regionalnej. Biuletyn KPZK PAN, 268, 26-38. https://doi.org/10.24425/117886

OECD (2010). Regional Development Policies in OECD Countries. Paris: OECD Publishing.

Pallagst, K., \& Caesar, B. (2018). Spatial Development Concepts - A cross-border planning instrument with a future ?! Experiences from the German borderlands. Borders in Perspective, 1, 9-20.

Przygodzki, Z. (2016). Kapitał terytorialny w rozwoju regionów. Acta Universitatis Lodziensis - Folia Oeconomica, 2(319), 83-97. https://doi.org/10.18778/0208-6018.319.06

Ratti, R. (1993). Spatial and Economic Effect of Frontiers. Overview of Traditional and New Ap-proaches and Theories of Border Area Development. In R., Ratti \& S., Reichmann (Eds.). Theory and Practice of Transborder Cooperation. Basel: Helbing \& Lichtenhahn.

Ricq, C. (2006). Handbook on Transfrontier Co-operation for Local and Regional Authorities in Europe. Council of Europe.

Rietveld, P. (2012). Barrier Effects of Borders: Implications for Border Crossing Infrastructures. European Journal of Transport and Infrastructure Research, 12(2). https://doi.org/10.18757/ EJTIR.2012.12.2.2959

Sohn, C. (2014). Modelling Cross-Border Integration: The Role of Borders as a Resource. Geopolitics, 19(3), 587-608. https://doi.org/10.1080/14650045.2014.913029

Sousa, L. D. (2013). Understanding European Cross-border Cooperation: A Framework for Analysis. Journal of European Integration, 35(6), 669-687. https://doi.org/10.1080/07036337.2012.711827

Svensson, S. (2015). The Bordered World of Cross-border Cooperation: The Determinants of Local Government Contact Networks within Euroregions. Regional \& Federal Studies, 25(3), 277-295. https://doi.org/10.1080/13597566.2015.1043995

Szafranek, E. (2019). Terytorializacja polityki rozwoju. Wdrażanie Zintegrowanych Inwestycji terytorialnych w obszarach funkcjonalnych miast w Polsce. Opole: Wydawnictwo Uniwersytetu Opolskiego.

Szczepaniec, M., \& Jurkiewicz, T. (2020). The role of virtual space in ensuring 'fair access' to banking services - results of empirical research conducted in the Polish SME sector. Europa XXI, 39, 63-81 https://doi.org/10.7163/Eu21.2019.39.2

TA 2030 (2020). Territorial Agenda 2030: A Future for All Places. Federal Ministry of the Interior, Building and Community of Germany. Retrieved from https://ec.europa.eu/regional_policy/sources/docgener/brochure/territorial_agenda_2030_en.pdf

Terlouw, K. (2012). Border Surfers and Euroregions: Unplanned Cross-Border Behaviour and Planned Territorial Structures of Cross-Border Governance. Planning Practice and Research, 27(3), 351-366. https://doi.org/10.1080/02697459.2012.670939 
Więckowski, M. (2018). Political borders under ecological control in the Polish borderlands. Geographia Polonica, 91(1), 127-138. https://doi.org/10.7163/GPol.0105

Więckowski, M. (2019). Od barier i izolacji do sieci i przestrzeni transgranicznej - konceptualizacja cyklu funkcjonowania granic państwowych [From barriers and isolation to transboundary space and networks - conceptualising ways in which state borders function]. Przeglqad Geograficzny, 91(4), 443466. https://doi.org/10.7163/PrzG.2019.4.1 